\title{
5. Ministerial Advisers: Democracy and Accountability
}

\author{
Yee-Fui $\mathrm{Ng}^{1}$
}

Ministerial advisers, personally appointed by Ministers, and working out of their private offices, have become an integral part of the political landscape over the last 40 years.

At federation, the very idea of ministerial advisers would have been denigrated, as the framers of the Constitution did not believe in 'making room for political friends'. ${ }^{2}$ They believed that it would lead to the 'spoils system' in the United States, where high and low official positions were used to reward friends and offer incentives to work for the political party, resulting in a system that was corrupt and inefficient.

Despite this, the role of ministerial advisers is now deeply entrenched in the political system. It all started with the informal 'kitchen cabinets', where a small group of trusted friends and advisers of the Minister gathered around the kitchen table to discuss political strategies. This has since become formalised and institutionalised into the role of the partisan ministerial adviser, as distinct from the impartial public service. The number of ministerial staff increased from 155 in April 1972 to 407 in June 2011; an increase of 163 per cent. ${ }^{3}$

There has been a distinct shift from federation, where the idea of ministerial advisers would have been derided, to a situation where ministerial advisers are now an integral and institutionalised aspect of governing the nation. Their position has been legislatively recognised and their salaries have been appropriated from public funds since $1980 .{ }^{4}$

There are questions about the democratic accountability of ministerial advisers. Ministerial advisers are not elected and are often derived from political party ranks and arguably do not enhance a participatory form of democracy. As such, a closer analysis of the democratic accountability of ministerial advisers is central to the theme of how law and democracy can interrelate to face new challenges.

\footnotetext{
1 Law Lecturer, RMIT. yeefui@gmail.com.

2 Official Report of the National Australasian Convention Debates, Adelaide, 19 April 1897, 916-7.

3 Anne Tiernan, Power Without Responsibility: Ministerial Staffers in Australian Governments from Whitlam to Howard (UNSW Press, 2007) 244; Australian Government Department of Finance and Deregulation, Members of Parliament (Staff) Act 1984 Annual Report 2010-11, http://www.finance.gov.au/publications/ mops_annual_reports/2010-2011/docs/MOPS_Annual_Report.pdf.

4 Members of Parliament (Staff) Act 1984 (Cth). See Appropriation Act (No 1) 2012-13 (Cth) Schedule 1; Appropriation Act (No 1) 1980-81 (Cth).
} 
In this chapter, I will first examine the issues that ministerial advisers pose to democracy. I then consider how relevant legal accountability mechanisms can be extended to ministerial advisers.

I argue that ministerial advisers are increasingly exercising executive power beyond what is allowed in the Statement of Standards for Ministerial Staff ${ }^{5}$ and should therefore be subject to legal accountability mechanisms such as appearing before parliamentary committees and judicial review under section 75(v) of the Constitution.

\section{Ministerial advisers and democracy}

As ministerial advisers are relatively new actors within the operation of the executive, it is necessary to examine the democratic issues relating to their role.

It can be argued that ministerial advisers enhance participatory democracy in two ways. First, it could be said that the mere existence of the position of ministerial adviser increases public participation in political processes. This is because members of the public can become ministerial advisers and seek to directly influence the political process.

However, ministerial advisers tend to come from a party political background. ${ }^{6}$ This means that although a greater number of people are able to influence the political process through becoming ministerial advisers, it tends to be party participation that predominates, rather than a broader form of public participation. In fact, this may exacerbate decision-making on purely political grounds, such as ministerial handouts to win marginal seats.

It may even be argued that there may be questionable actions by ministerial advisers that could be seen to indirectly undermine responsible government. An example of this is the actions of a United Kingdom special adviser, Damian McBride, who collaborated in setting up a blog disseminating fabricated rumours about the sex lives of Conservative politicians in order to undermine their reputations. ${ }^{7}$ This kind of purely self-interested, party political activity may be seen to indirectly undermine responsible government by distracting political debate and parliamentary scrutiny of executive action from substantive policy issues towards fabricated issues about politicians' private lives.

5 Statement of Standards for Ministerial Staff, http://www.smos.gov.au/resources/statement-of-standards.html.

6 Maria Maley, Partisans at the Centre of Government: the Role of Ministerial Advisers in the Keating Government 1991-96 (PhD Thesis, The Australian National University, 2002) 211-12; Benito Folino, A Government of Advisers: The Role, Influence and Accountability of Ministerial Advisers in the New South Wales Political System (PhD Thesis, University of New South Wales, 2010) 120-3.

7 'Damian McBride's Departure Marks the End of a Bumpy Whitehall Career', Guardian, (United Kingdom) 13 April 2009, http://www.guardian.co.uk/politics/2009/apr/13/labour-damian-mcbride-resignation. 
Secondly, ministerial advisers can be seen to benefit democracy because they interact with interest groups on behalf of their Minister. This means that there are a wider range of interest groups that can lobby the Minister through the conduit of ministerial advisers, which may increase participatory democracy. However, ministerial advisers also filter information that reaches the Minister. Thus, it is unclear whether the presence of ministerial advisers does increase the number of interest groups reaching the attention of the Minister.

It is necessary to consider the democratic accountability of ministerial advisers. The Australian constitutional system operates within a framework of democratic accountability. Democratic accountability can be explained through a vertical principal-agent relationship, where the 'principal' is 'the people' who agree to be governed by its 'agents' (the elected politicians, executive, judiciary, legislature) in exchange for the protection of individual rights (the protection of life, liberty and property). ${ }^{8}$ The principal holds the agents accountable through various means, such as elections or legal mechanisms. ${ }^{9}$ Therefore, the sovereign position in a democracy is the public, and accountability focuses on the obligation of officials to justify their public decisions and their exercises of public power to the people. ${ }^{10}$

In addition, there are also horizontal accountability structures, which are a system of checks and balances between government agents and institutions, ${ }^{11}$ such as ministerial advisers. As ministerial advisers are not elected by the people, there is no direct link between the 'agent' (ministerial advisers) that should respond to the needs of the 'principal' (the public). Despite this, ministerial advisers operate as significant actors within the executive. Therefore, there have to be systems in place ensuring that ministerial advisers are accountable, much like the elected representatives.

This chapter will examine the current regulation of ministerial advisers. The chapter will also identify accountability gaps and suggest how these can be addressed.

8 Christine B Harrington and Z Umut Turem, Accounting for Accountability in Neoliberal Regulatory Regimes' in Michael W Dowdle (ed), Public Accountability: Designs, Dilemmas and Experiences (Cambridge University Press, 2006) 198-9.

9 ibid 199.

10 ibid.

11 ibid. 


\section{Accountability of ministerial advisers}

There have been concerns about the accountability of ministerial advisers as seen by prominent events such as the 'Children Overboard' incident. ${ }^{12}$

In the 'Children Overboard' incident in 2001, Ministers made public statements that asylum seekers had thrown their own children overboard. For instance, the Prime Minister said, 'I don't want people like that in Australia. Genuine refugees don't do that ... They hang on to their children.' ${ }^{\prime 3}$

Within a few days, several public servants found out that the children overboard story was false. ${ }^{14}$ They notified a ministerial adviser of the Defence Minister about this. ${ }^{15}$ Nonetheless, Ministers continued to make public statements about asylum seekers throwing children overboard as part of an election campaign. When pressed for evidence, the press secretary of the Defence Minister asked a public servant to email two photographs to him. ${ }^{16}$ The photos were actually of two brave navy sailors who rescued terrified asylum seekers and their children in the open sea when their boat sank. The press secretary was informed soon after that the photos were not of the children overboard incident, but of the rescue operation. ${ }^{17}$

Despite this, the press secretary asked a public servant for another copy of the photo. He was insistent that the photo be emailed immediately. 'I am your boss', he said to the public servant. He refused to hang up until the photos were emailed to him. The Ministers released these photographs to the media as evidence of children being thrown overboard. ${ }^{18}$ A Senate Select Committee was formed to investigate the 'Children Overboard' incident. The government refused to allow ministerial advisers to appear before the Senate Committee. The Senate Committee was highly critical of this, stating that '[s] uch bans and refusals are anathema to accountability'. ${ }^{19}$ Despite this, the Senate Committee

\footnotetext{
12 There are other incidents at State level such as the Hotel Windsor incident and the 'leaked tapes' crisis in Victoria. See Ombudsman Victoria, 'Ombudsman Investigation into the Probity of the Hotel Windsor Redevelopment' (2011), http://www.ombudsman.vic.gov.au/resources/documents/Ombudsman investigation_into_the_probity_of_The_Hotel_Windsor_redevelopment.pdf; James Campbell, ‘Tony Nutt told Police Minister Peter Ryan "to put a sock in it"', The Herald Sun (Melbourne), 4 March 2013, http:// www.heraldsun.com.au/news/victoria/tony-nutt-told-police-minister-peter-ryan-to-put-a-sock-in-it/storye6frf7kx-1226589560123.

13 Christine B Harrington and Z Umut Turem, Accounting for Accountability in Neoliberal Regulatory Regimes' in Michael W Dowdle (ed), Public Accountability: Designs, Dilemmas and Experiences (Cambridge University Press, 2006) 251.

14 Commonwealth Senate Select Committee, A Certain Maritime Incident (2002) xxxvi.

15 Patrick Weller, Don't Tell the Prime Minister (Scribe Publications, 2002) 26.

16 David Marr and Marian Wilkinson, Dark Victory (Allen \& Unwin, 2nd ed, 2004) 266-7.

17 ibid.

18 ibid 35.

19 Commonwealth Senate Select Committee, A Certain Maritime Incident (2002) xxxiv.
} 
did not seek to compel the attendance of ministerial advisers, stating that it would be unjust to impose a penalty on a ministerial adviser who did not appear on the direction of their Minister. ${ }^{20}$

In 2004, one of these ministerial advisers, Mike Scrafton, wrote an article in a newspaper stating that he told the Prime Minister that claims of children being thrown overboard were unsubstantiated before the federal election, contrary to the Prime Minister's denials. ${ }^{21}$ A special Senate inquiry was established to hear his evidence. Scrafton passed a polygraph test for his statutory declaration. ${ }^{22}$ The report indicated that the ministerial adviser had briefed the Ministers on the falsity of the children overboard allegations prior to the elections and the Ministers had chosen not to correct the public record. ${ }^{23}$

This example highlights an accountability gap, making it necessary to examine the current regulation of ministerial advisers and how further accountability mechanisms can be applied to them.

\section{Current regulation of ministerial advisers}

Ministerial advisers are employed under the Members of Parliament (Staff) Act 1984 (Cth). ${ }^{24}$ The terms and conditions of employment of ministerial advisers are subject to the determination of the employing Minister, ${ }^{25}$ with the Prime Minister being able to vary the employment terms and conditions. ${ }^{26}$

Section 31 of the Act requires the Prime Minister to table a yearly report to Parliament setting out the name of each consultant engaged by all Ministers, the period of engagement of the consultant, and the tasks specified. ${ }^{27}$ Ministerial advisers are not engaged as consultants and therefore do not fall within the scope of this provision. Nevertheless, since 2007-08, the government has tabled annual reports providing information about the numbers of ministerial advisers employed, their classification levels, and their salaries and benefits. ${ }^{28}$

Ministerial advisers are also subject to a Statement of Standards, setting out the standards that they are expected to meet in performing their duties. ${ }^{29}$ The

\footnotetext{
20 Commonwealth Senate Select Committee, A Certain Maritime Incident (2002) xxxiv-xxxv.

21 Commonwealth Senate Select Committee on the Scrafton Evidence, Report (2004) 1-2.

22 ibid 68; Text of Mike Scrafton's Letter to the Australia of 4 September 2004, Appendix 4 of Commonwealth Senate Select Committee on the Scrafton Evidence, Report (2004).

23 Commonwealth Senate Select Committee on the Scrafton Evidence, Report (2004) 1-2, 48.

24 Members of Parliament (Staff) Act 1984 (Cth) s 13 ('MOPS Act').

25 ibid s 14(1).

26 ibid s 14(3).

27 ibid s 31.

28 See Members of Parliament (Staff) Act 1984 Annual Reports, http://www.finance.gov.au/publications/ mops_annual_reports/index.html.

29 Statement of Standards for Ministerial Staff, http://www.smos.gov.au/resources/statement-of-standards.html.
} 
Statement of Standards include acknowledgement that ministerial staff do not have the power to direct public servants in their own right. ${ }^{30}$ In addition, it recognises that executive decisions are the preserve of Ministers and public servants, and not ministerial staff acting in their own right. ${ }^{31}$ Further, ministerial advisers have the duty to facilitate direct and effective communication between their Minister's department and their Minister. ${ }^{32}$ Implementation and sanctions under the Standards are handled internally by the executive through the Prime Minister's Office. ${ }^{33}$ This means that any breaches of the Standards by ministerial advisers such as those in the 'Children Overboard' incident would be handled behind closed doors, without the scrutiny of Parliament or any external bodies.

The Statement of Standards seems to suggest that ministerial advisers have a very limited role and are merely conduits between the Ministers and the public service. Nevertheless, ministerial advisers have increasingly extensive roles, including advising on public policy, media, political, parliamentary management and party management matters. ${ }^{34}$

Tony Nutt, the former Chief of Staff of the Victorian Premier, in the leaked conversations to the Herald Sun, sums it up very colourfully:

[A] ministerial adviser deals with the press. A ministerial adviser handles the politics. A ministerial adviser talks to the union. All of that happens every day of the week, everywhere in Australia all the time. Including frankly, the odd bit of, you know, ancient Spanish practices and a bit of bastardry on the way through. That's all the nature of politics. ${ }^{35}$

Significantly, there are instances where certain ministerial advisers act on behalf of their Minister and potentially exercise executive power. Dr Maria Maley referred to this as advisers becoming 'surrogates' and making minor decisions in the Minister's name, ${ }^{36}$ while Jack Waterford noted that some Ministers 'effectively delegate parts of their work to individual staffers, expecting them to make

30 ibid cl 11.

31 ibid cl 12.

32 ibid cl 13.

33 ibid. Implementation of the Standards is the responsibility of the Prime Minister's Office and the Government Staffing Committee. Sanctions imposed under the Standards are determined after consultation with the relevant Minister by the Prime Minister's Chief of Staff, acting on advice from the Government Staffing Committee.

34 The Herald and Weekly Times Pty Limited $v$ The Office of the Premier (General) [2012] VCAT 967 [22].

35 James Campbell, 'Tony Nutt told Police Minister Peter Ryan "to put a sock in it"', The Herald Sun (Melbourne), 4 March 2013, http://www.heraldsun.com.au/news/victoria/tony-nutt-told-police-ministerpeter-ryan-to-put-a-sock-in-it/story-e6frf7kx-1226589560123.

36 Maria Maley, Partisans at the Centre of Government: the Role of Ministerial Advisers in the Keating Government 1991-96 (PhD Thesis, The Australian National University, 2002) 123. Cited in Commonwealth Senate, Finance and Public Administration References Committee, Staff Employed under the Members of Parliament (Staff) Act 1984 (2003) 16. 
routine decisions and to process approvals without any need for consultation' ${ }^{37}$ Harry Evans, a former Clerk of the Senate, has stated that ministerial advisers 'act as de facto assistant ministers and participate in government activities as such' ${ }^{38}$ Further, the Senate Committee for the 'Children Overboard' incident found that 'it can no longer be assumed that [ministerial] advisers act at the express direction of ministers and/or with their knowledge and consent. Increasingly, advisers are wielding executive power in their own right. ${ }^{\prime 39}$

In this chapter, I focus on ministerial advisers with the role of acting on behalf of the Minister, as this is their most controversial role. I will consider whether in some situations ministerial advisers exercise executive power.

\section{Do ministerial advisers exercise executive power?}

The constitutional framework for the executive is characterised by large gaps and eloquent silences. The content of Commonwealth executive power was deliberately not expressly defined by the drafters of the Constitution. Sir Alfred Deakin stated in relation to section 61 :
No exhaustive definition is attempted in the Constitution - obviously because any such attempt would have involved a risk of undue, and perhaps unintentional, limitation of the executive power. Had it been intended to limit the scope of the executive power to matters on which the Commonwealth Parliament had legislated, nothing would have been easier than to say so. ${ }^{40}$

Therefore, executive power is an elusive and slippery concept defying the strictures of precise definition. ${ }^{41}$ Even the scope of executive power is uncertain, with only incremental clarification through case law over the years.

Technically, according to section 61 of the Constitution, the Commonwealth's executive power is vested in the Queen and is exercisable by the GovernorGeneral. However, there is a constitutional convention that the Governor-

\footnotetext{
37 Jack Waterford, 'Reining in Political Staff and Outsiders', Public Sector Informer (Canberra Times) December 2001, 6. Cited in Commonwealth Senate, Finance and Public Administration References Committee, Staff Employed under the Members of Parliament (Staff) Act 1984 (2003) 16.

38 Clerk of the Senate, Correspondence to Senator Cook, 22 March 2002, 4.

39 Commonwealth Senate Select Committee, A Certain Maritime Incident (2002) xxxvii.

40 Alfred Deakin, 'Channel of Communication with Imperial Government: Position of Consuls: Executive Power of Commonwealth', in P Brazil and M Mitchell (eds), Opinions of Attorneys-General of the Commonwealth of Australia: Volume 1: 1901-14 (Canberra, AGPS, 1981) 129, 130.

41 In Davis v Commonwealth (1988) 166 CLR 79, 92, Mason CJ, Deane and Gaudron JJ acknowledged that the scope of the executive power of the Commonwealth had 'often been discussed but never defined'. In Pape $v$ Commissioner of Taxation (2009) 238 CLR 1, the judges do not attempt a full discussion on the scope of executive power.
} 
General only exercises executive power on the advice of Ministers. ${ }^{42}$ Thus, in practice, executive power is exercised by Ministers, as the government acts through Ministers who administer government departments under section 64 of the Constitution. ${ }^{43}$ In addition, Ministers may exercise executive power conferred by statute. ${ }^{44}$ However, it is recognised that efficient government administration may require in many circumstances that a Minister act through another person. ${ }^{45}$ As stated by Staughton LJ in $R v$ Secretary of State for the Home Department; Ex parte Doody:

Parliament frequently confers powers on a minister who is the political head of a department. Much less frequently, it confers powers on an official of a particular description or grade ... But it is absurd to suppose that every power which is conferred on the political head of a department must be exercised by him and him alone. It is in general sufficient that the power is exercised by a junior minister or an official on his behalf. ${ }^{46}$

Ministers do not have to personally make all decisions themselves. Legislation may confer the ability for Ministers to delegate their powers. ${ }^{47}$ Alternatively, legislation may specify that a public servant is to exercise powers under the statute. ${ }^{48}$ Therefore, public servants may exercise executive power by virtue of authority granted by statute or power delegated by the Minister.

The Statement of Standards for ministerial advisers seems to envisage that executive power is solely the province of Ministers and public servants, not ministerial advisers. ${ }^{49}$ However, I argue that, in certain circumstances, ministerial advisers can and do exercise executive power. In particular, according to the Carltona or 'alter ego' principle, ${ }^{50}$ Ministers may have agents who are authorised to carry out certain tasks without having a formal delegation to do so. According to this principle, constitutionally the agent's decision is deemed

42 Ian Killey, Constitutional Conventions in Australia: An Introduction to the Unwritten Rules of Australia's Constitution (Australian Scholarly Publishing, 2nd ed, 2012) 130.

43 Ryder v Foley (1906) 4 CLR 422, 432-3. See P H Lane, Lane's Commentary on the Australian Constitution (LBC Information Services, 2nd ed, 1997) 433.

44 P H Lane, Lane's Commentary on the Australian Constitution (LBC Information Services, 2nd ed, 1997) 433.

$45 R v$ Secretary of State for the Home Department; Ex parte Doody [1993] QB 157, 194, $R v$ Secretary of State for the Home Department; Ex parte Doody [1994] 1 AC 531, 566. Applied in Australia by Attorney General $v$ Foster (1999) 84 FCR 582.

46 [1993] QB 157, 194. R $v$ Secretary of State for the Home Department; Ex parte Doody [1993] QB 157, 194, adopted on appeal in the House of Lords in $R v$ Secretary of State for the Home Department; Ex parte Doody [1994] 1 AC 531, 566. Cited with approval in Attorney General v Foster (1999) 84 FCR 582.

$47 \quad R v$ Secretary of State for the Home Department; Ex parte Doody [1993] QB 157, 194.

48 ibid.

49 Statement of Standards for Ministerial Staff, http://www.smos.gov.au/resources/statement-of-standards.html.

50 Carltona Ltd $v$ Commissioners of Works [1943] 2 All ER 560, 563. Applied in Australia by O'Reilly $v$ State Bank of Victoria Commissioner (1983) 153 CLR 1, 11. 
to be the Minister's decision. ${ }^{51}$ The Minister remains responsible and answerable to Parliament for anything his/her officials have done under the Minister's authority. ${ }^{52}$

This is illustrated by the case of Ozmanian $v$ Minister for Immigration, Local Government and Ethnic Affairs. ${ }^{53}$ In this case, the Minister authorised procedures for dealing with the large number of requests for ministerial interventions to grant protection visas 'in the public interest'. A Senior Adviser of the Minister would sign a letter on behalf of the Minister about whether the Minister would consider the application for a protection visa. This meant that a ministerial adviser was in effect signing letters determining substantive issues affecting the rights of asylum-seekers. In Ozmanian, although the letter was said to be sent at the request of the Minister, the Minister had in fact never seen the letter. ${ }^{54}$ This would be an exercise of executive power if it was held to be valid.

At first instance, Merkel $\mathrm{J}$ held that the Senior Adviser made the decision on behalf of the Minister. ${ }^{55}$ Although the decision was not made by the Minister, it was a decision made under the authority of the Migration Act 1958 (Cth) ('Migration $A c t$ ') as it was in accordance with the general procedures established with the Minister's authority. ${ }^{56}$

Despite this, Merkel J stated that the Migration Act detailed powers of delegation making it less likely that the Carltona principle would apply. ${ }^{57}$ Further, courts are reluctant to utilise the Carltona principle where the exercise of that power may have drastic consequences upon an individual, such as visa decisions. ${ }^{58}$ Hence, the power under the Migration Act had to be exercised by the Minister personally or an authorised delegate. ${ }^{59}$ This means that the decision made by the Senior Adviser was invalid. ${ }^{60}$

Merkel J's decision was overturned by the Full Federal Court on other grounds. The Full Court did not find it necessary to determine the ministerial adviser issue. ${ }^{61}$ Therefore the law in this area is not settled.

Ozmanian is an instance of a ministerial adviser exercising executive power, contrary to the Statement of Standards. However, there are no external

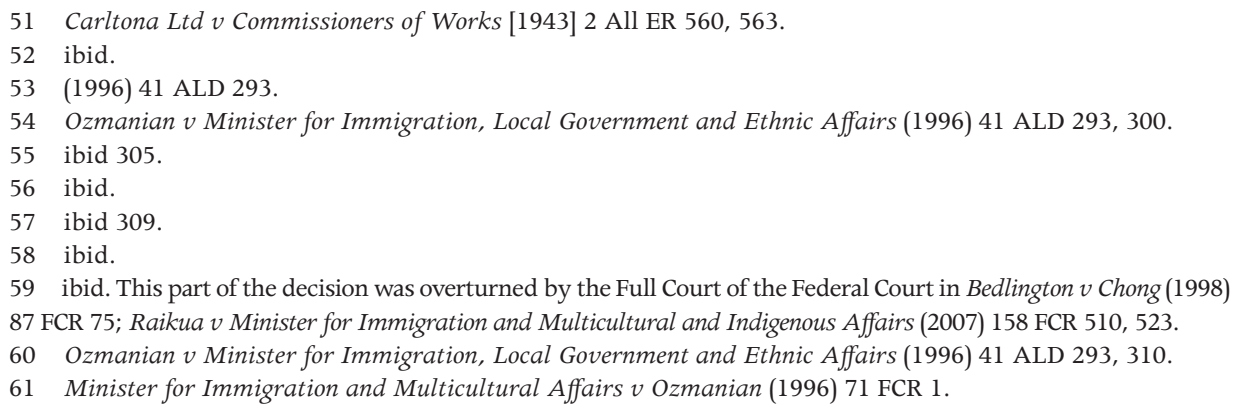


enforcement mechanisms under the Standards, and the Standards are not legislatively enshrined. Therefore, courts do not take the Standards into account. Nevertheless, the courts have the jurisdiction to police the boundaries of executive power. The courts have a few options. First, the courts could decide that a particular aspect of executive power is non-delegable to ministerial advisers, akin to Merkel J's judgment. This is more likely in decisions with drastic consequences for individuals and where there are existing powers of delegation within the legislation. Decisions involving fundamental rights of life and liberty should arguably only be exercised by the Minister or an authorised delegate due to the potentially significant negative impact on individuals. The power of delegation within legislation suggests that delegation should be conducted within the legislative framework. Where the court decides that decisions are non-delegable, the decisions of ministerial advisers are invalid.

Alternately, the courts may decide that the Carltona principle may apply to ministerial advisers based on statutory interpretation. In this situation, ministerial advisers are acting as the informal agent of the Minister and are able to make executive decisions on the Minister's behalf. According to case law, the person exercising the power must be an 'appropriate' official. ${ }^{62}$ Mark Campbell has found that, in general, courts have accepted that it is for the Minister to decide who is an appropriate official to exercise power, ${ }^{63}$ and the court tends to defer to the Minister's choice. As Carltona indicates, even if the Minister gave responsibility to an official who is too junior, it is the Minister who would answer for this in Parliament. ${ }^{64}$ This suggests that courts would not supervise the selection of the official, even if the official is junior.

However, as Professor Mark Freedland argues, Carltona was decided in a legal and constitutional environment where 'extreme importance' was attached to ministerial responsibility. ${ }^{65}$ Carltona is predicated upon the Minister actually taking responsibility in Parliament for the wrong choice of an official. However, the application of ministerial responsibility in Australia has been watered down significantly. ${ }^{66}$ Thus it is reasonable to more cautiously apply Carltona in modern times and not simply assume that all public officials would be covered by this principle.

62 Carltona Ltd $v$ Commissioners of Works [1943] 2 All ER 560; Re Golden Chemical Products Ltd [1976] 2 All ER 543; $R v$ Secretary of State for the Home Department; Ex parte Oladehinde [1991] AC 254; $R$ (on the application of Chief Constable of West Midlands) v Birmingham Justices [2002] EWHC 1087 [10].

63 Mark Campbell, 'The Carltona Doctrine' (2007) 18 Public Law Review 251, 261. Rv NDT Ventures Ltd (2001) 4 Admin LR 110 (4th); Re Golden Chemical Products Ltd [1976] 2 All ER 543.

64 Carltona Ltd $v$ Commissioners of Works [1943] 2 All ER 560, 563.

65 Mark Freedland, 'The Rule against Delegation and the Carltona Doctrine in an Agency Context' (1996) Public Law 19, 24-5.

66 See Ian Killey, Constitutional Conventions in Australia: An Introduction to the Unwritten Rules of Australia's Constitution (Australian Scholarly Publishing, 2nd ed, 2012) 87. 
There are limits to the Minister's choice of agent. The courts are likely to inquire into the identity of the Minister's agent if the Minister's choice was irrational or beyond the Minister's powers. ${ }^{67}$ If an Immigration Minister authorised a low level administrative assistant from the Department of Tourism to make visa decisions, for example, the courts would be likely to intercede, as this decision would be illogical and unreasonable: the Minister has qualified staff in his/her department to handle visa matters and it does not make sense for an assistant in the Department of Tourism without the requisite skills to make migration decisions. ${ }^{68}$

In addition, where the decision affects individual rights and liberties and involves coercive powers, the courts may also look more closely at the Minister's choice of agent. This is because executive and statutory decisions depriving an individual of rights and liberties are grave and should not be entrusted to unqualified individuals. For instance, if an Immigration Minister authorised a low-ranking administrative assistant to make deportation decisions, which have grave consequences for individuals, this activity would not be upheld by the courts. However, if the Immigration Minister granted the same power to a senior ministerial adviser, the courts would tend not to question the choice of the adviser.

In short, Ozmanian demonstrates that there are instances where ministerial advisers in effect exercise executive power. Where ministerial advisers exercise executive power, they are operating as part of the executive. Therefore, they should be subject to appropriate accountability mechanisms. I will now briefly outline two possible options for accountability: to Parliament and to the courts.

\section{Accountability to Parliament}

The recent High Court decision of Williams $v$ Commonwealth ('Williams') emphasises the concept of responsible government, with six judges utilising responsible government as the basis of their decisions. ${ }^{69}$ The majority of French CJ, Gummow, Bell and Crennan JJ utilised responsible government to hold that the Commonwealth needs statutory authority to enter into contracts and spend public money, subject to limited exceptions. ${ }^{70}$ French CJ held that a broad conception of the Commonwealth executive's power to contract would undermine parliamentary control of the executive branch and weaken the

67 Mark Campbell, 'The Carltona Doctrine' (2007) 18 Public Law Review 261. R (on the application of Chief Constable of West Midlands) v Birmingham Justices [2002] EWHC 1087 (Admin) [16].

68 See Mark Campbell, 'The Carltona Doctrine' (2007) 18 Public Law Review 262.

69 Williams $v$ Commonwealth (2012) 248 CLR 156, 179-80 [4] French CJ, 239 [161] Gummow and Bell JJ, 357-8 [542]-[544] (Crennan J).

70 ibid. The exceptions include prerogative powers, ordinary and well-recognised functions of government, nationhood power and incidental power. Williams (2012) 248 CLR 156,191 [34] French CJ, 342 [484] Crennan J. 
role of the Senate. ${ }^{71}$ Crennan $\mathrm{J}$ also emphasised the institution of responsible government, where the executive's primary responsibility in its prosecution of government is owed to Parliament. ${ }^{72}$ Crennan $\mathrm{J}$ noted that this accountability came to be expressed in terms of the need for the executive to enjoy the confidence of Parliament in dealing with finance, as the arm of government most immediately representing and therefore responsible to the people (the electors). ${ }^{73}$ Gummow and Bell JJ held that an unqualified executive power to contract and to spend would undermine the basic assumption of legislative predominance inherited from the United Kingdom and would distort the relationship between Chapter I and Chapter II of the Constitution. ${ }^{74}$

In Williams, responsible government is more central to the reasoning process of the judges than in Lange $v$ Australian Broadcasting Corporation ('Lange'). ${ }^{75}$ According to the High Court in Lange, responsible government could create limits on executive power, not just legislative power. ${ }^{76}$ This concept of responsible government being a fetter on executive power was taken further in Williams, as the High Court utilised responsible government as a restraint on the Commonwealth Executive's ability to circumvent parliamentary processes. This resulted in a substantive limitation, that is, a significant reduction of Commonwealth executive power in contracting without statutory authority.

Therefore, Williams may represent a resurgence of responsible government and the utilisation of parliamentary accountability as a mechanism for constraining the actions of the Commonwealth executive.

Under the doctrine of responsible government, the executive is responsible to the legislature. As the High Court stated in Egan $v$ Willis, the contemporary position in Australia is that while the primary role of Parliament is to pass laws, it also has important functions to question and criticise the government on behalf of the people', and 'to secure accountability of government activity is the very essence of responsible government' ${ }^{77}$ According to John Stuart Mill, the task of the Legislature is to 'watch and control the government: to throw the light of publicity on its acts'.$^{78}$

Sir Samuel Griffith provided an explanation about the main principles of responsible government, that is, the Crown does not act on its own volition, but

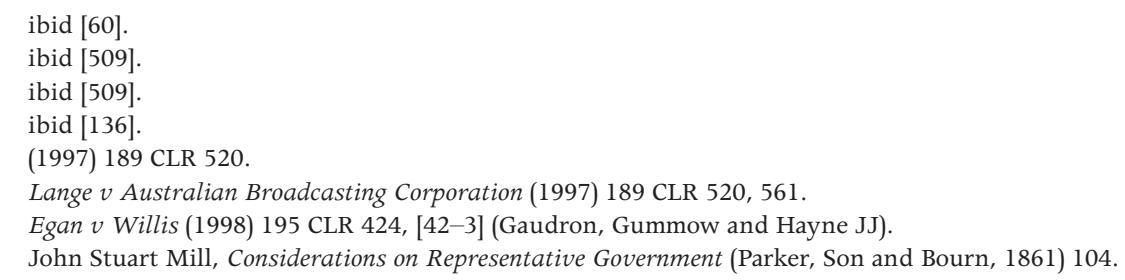


rather follows advice of Ministers. ${ }^{79}$ Therefore Ministers bear the responsibility for the decisions that they make. Ministers are responsible to Parliament and can only hold their position with the confidence of the people, reflected by the House of Representatives in Parliament. ${ }^{80}$ The requirement of confidence from the House of Representatives is based on the principle that the House of Representatives is the people's house, and represents the interests of the people, while the Senate is the State's house. As Sir John Quick and Sir Robert Garran said: 'The Senate represents the States as political units. The House represents the people as individual units. ${ }^{81}$ Therefore, the principle of responsible government has a democratic element and is linked with the concept of representative democracy as it provides that the executive government is accountable, through the mechanisms of Parliament, to the people who elected the executive.

In terms of ministerial advisers, I argue that because their salary is appropriated from public fund ${ }^{82}$ and as they may increasingly be exercising executive power, the principles of responsible government apply to them. Hence, ministerial advisers should be accountable to Parliament by being required to appear before parliamentary committees, such as those established for the 'Children Overboard' incident.

At the Commonwealth level, parliamentary privileges and immunities are governed by the Parliamentary Privileges Act 1987 (Cth). This Act preserves the operation of section 49 of the Constitution, that Commonwealth Members of Parliament have the powers, privileges and immunities of the United Kingdom House of Commons existing on 1 January 1901. ${ }^{83}$ According to Lange, section 49 of the Constitution provides the source of coercive authority for each House of Parliament to 'summon witnesses, or to require the production of documents, under pain of punishment for contempt'. ${ }^{84}$ Therefore, at the Commonwealth level, the Senate has the power to compel the production of persons and documents. This includes the power to compel ministerial advisers to attend, to give evidence and produce documents to a Senate Committee.

79 Samuel Griffith, 'Notes on Australian Federation: Its Nature and Probable Effects' (paper presented to the Government of Queensland, 1896) 17-8, http://adc.library.usyd.edu.au/data-2/fed0017.pdf.

80 ibid.

81 John Quick and Robert Randolph Garran, The Annotated Constitution of the Australian Commonwealth (Angus \& Robertson, 1901) 447.

82 There has been a yearly appropriation of ministerial adviser salaries in Parliament since 1980 as part of the 'ordinary services of government'. See for example Appropriation Act (No 1) 1980-81 (Cth), Appropriation Act (No 1) 2012-13 (Cth) Schedule 1, Department of Finance and Administration, Outcome 3.

83 Parliamentary Privileges Act 1987 (Cth) s 5.

84 Lange (1997) 189 CLR 520, 557-9. See also Parliament of Australia, Orders for Production of Documents (2005), http://www.aph.gov.au/About_Parliament/Senate/Powers_practice_n_procedures/guides/briefnoll. 
Traditionally ministerial advisers are seen to be accountable to their Minister personally, while Ministers are accountable to Parliament. ${ }^{85}$ It has been argued that ministerial advisers are thus not required to appear before parliamentary committees. As a result, ministerial advisers have generally tended not to appear before parliamentary committees based on the instructions of their Minister.

However, this argument is weak, as public servants are similarly accountable to their Minister, who is then linked by the chain of accountability to Parliament. Unlike ministerial advisers, public servants routinely appear before parliamentary committees. Their presence is to give an account of their actions to Parliament, while responsibility for their actions fall on their Minister, who may be censured in Parliament. ${ }^{86}$ The appearance of ministerial advisers before parliamentary committees would be to perform a similar function.

In situations such as the 'Children Overboard' incident, the fact that ministerial advisers did not appear before the parliamentary committees allowed the Ministers to escape accountability by claiming they were not advised of the fact that no children had been thrown overboard, while ministerial advisers did not present their account as they did not appear before Parliament. This creates an accountability gap, where Ministers are able to plead ignorance to controversial policies and decisions and escape accountability in Parliament. Therefore, in accordance with recommendations of a Senate Committee, ministerial advisers should appear before parliamentary committees, particularly where a Minister has renounced a ministerial adviser's action, refused to answer questions regarding the conduct of a ministerial adviser, critical information has been received from a Minister's office but is not communicated to a Minister, or critical instructions have emanated from a Minister's office and not the Minister. ${ }^{87}$

There is no strong rationale why ministerial advisers do not appear before parliamentary committees. The best way for this to happen is with the agreement between Parliament and the government for ministerial advisers to appear based on negotiated guidelines. This has previously been done for public servants. ${ }^{88}$ Otherwise, there will be a perpetual battle of wills between Parliament, with their strong powers, and government, with their fondness for political escapism.

85 H Collins, 'What Shall We Do With the Westminster Model?' in R Smith and P Weller (eds), Public Service Inquiries in Australia (University of Queensland Press, 1978) 366.

86 Senate Finance and Public Administration References Committee, 'Staff Employed Under the Members of Parliament (Staff) Act 1984' (2003) xii.

87 ibid.

88 See Government Guidelines for Official Witnesses before Parliamentary Committees and Related Matters, http://www.dpmc.gov.au/guidelines/. 


\section{Accountability to the courts}

Another potential accountability mechanism is if courts are able to judicially review the executive actions of ministerial advisers. To this end, it can be argued that ministerial advisers are 'officers of the Commonwealth' under section 75(v) of the Constitution. Section $75(\mathrm{v})$ is said to entrench a minimum provision of judicial review. ${ }^{89}$ This means that Parliament is unable to remove the jurisdiction of the High Court 'by any form of words or any device'.${ }^{90}$

It is clear that Ministers, ${ }^{91}$ public servants ${ }^{92}$ and Minister's delegates ${ }^{93}$ are 'officers of the Commonwealth'. However, this issue has not been determined for ministerial advisers.

According to case law, an 'officer of the Commonwealth' has to have an office of some conceivable tenure, be directly appointed by the Commonwealth, accept office and salary from the Commonwealth, and be removable by the Commonwealth..$^{94}$ In $R v$ Murray and Cormie; Ex parte Commonwealth, Isaacs J stated:

The expression 'officer of the Commonwealth' has not a fictional meaning. It has a real meaning that the person referred to is individually appointed by the Commonwealth; and therefore the Constitution takes his Commonwealth official position as in itself a sufficient element to attract the original jurisdiction of the High Court. ${ }^{95}$

In Williams, the fact that Commonwealth funding was used to employ school chaplains was not considered enough for the school chaplains to hold an office under the Commonwealth under section 116 of the Constitution. ${ }^{96}$

Gummow and Bell JJ, with French CJ, Crennan and Kiefel JJ agreeing, held that the school chaplains were not 'offices ... under the Commonwealth' under section 116 of the Constitution. ${ }^{97}$ For these judges, the presence of a contractual

\footnotetext{
89 Plaintiff S157/2002 v Commonwealth (2003) 211 CLR 476, [103] (Gaudron, McHugh, Gummow, Kirby and Hayne JJ).

$90 R v$ Commonwealth Court of Conciliation \& Arbitration; Ex parte Brisbane Tramways Co Ltd (1914) 18 CLR 54, 59.

91 Church of Scientology Inc $v$ Woodward (1982) 154 CLR 25, 65.

$92 R v$ Commonwealth Court of Conciliation \& Arbitration; Ex parte Brisbane Tramways Co Ltd (1914) 18 CLR 54, 66, 86, Church of Scientology Inc $v$ Woodward (1982) 154 CLR 25, 66. Queensland Medical Laboratory $v$ Blewett (1988) 84 ALR 615, Minister for Immigration and Multicultural Affairs v Jia (2001) 205 CLR 507, 545, Re Minister for Immigration and Multicultural Affairs; ex parte Epeabaka (2001) 106 CLR 128, 135, Re Patterson; ex parte Taylor (2001) 207 CLR 291, 498.

93 Carter $v$ Minister for Aboriginal Affairs (2005) 143 FCR 383, 393.

$94 R v$ Murray and Cormie; Ex parte Commonwealth (1916) 22 CLR 437, 452-3, $R$ v Commonwealth Court of Conciliation \& Arbitration; Ex parte Brisbane Tramways Co Ltd (1914) 18 CLR 54.

$95 R$ v Murray and Cormie; Ex parte Commonwealth (1916) 22 CLR 437, 452-3.

96 Williams v Commonwealth [2012] HCA 23 [109]. See also Mazukov v University of Tasmania [2002] FCAFC 166.

97 ibid (French CJ) [107]-[110] (Gummow and Bell JJ), [476] (Crennan J), [597] Kiefel J.
} 
relationship with the Commonwealth was material. ${ }^{98}$ For them, the term 'under' indicates a requirement for a closer connection to the Commonwealth than merely being engaged by a private body that receives funding from the Commonwealth. ${ }^{99}$ This can also be said of the term 'officer of the Commonwealth'.

Heydon J also preferred a narrow reading of 'an office under the Commonwealth' to prevent radical expansion of the opportunities for litigation under section 75(v). He suggested that an 'officer' has to have a direct relationship with the Commonwealth, and the Commonwealth may specify qualifications before particular appointments may be made or continued. ${ }^{100}$ Heydon J held that chaplains did not have an office under the Commonwealth due to the lack of legal relationship between the chaplains and the Commonwealth, which resulted in the inability of the Commonwealth to appoint, control and dismiss the chaplains. ${ }^{101}$

This suggests that a level of control by the Commonwealth is required to satisfy the criteria of 'officer of the Commonwealth'. Thus, Williams may indicate that there is a spectrum. On one end are Ministers and public servants with a close relationship to the Commonwealth and who are fully controlled by the Commonwealth-entities that are clearly covered by section $75(\mathrm{v})$. On the other end of the spectrum are persons or entities without a direct relationship with the Commonwealth, that are unable to be controlled by the Commonwealth, and who are not covered by section $75(\mathrm{v})$. The question is where the line is drawn for entities that fall somewhere in the middle of the spectrum, such as ministerial advisers.

Ministerial advisers are appointed by Ministers and are engaged under section 13 of the Members of Parliament (Staff) Act 1984 (Cth) ('MOPS Act'). ${ }^{102}$ Ministerial advisers are removable by Ministers. Under section 16(3) of the MOPS Act, a Minister may at any time terminate the employment of ministerial advisers. ${ }^{103}$ Ministers have full control of the terms and conditions of employment of ministerial advisers. Under the MOPS Act, the terms of conditions of employment of ministerial advisers are subject to the determination of the employing Minister, ${ }^{104}$ with the Prime Minister being able to vary employment terms and conditions. ${ }^{105}$ The Prime Minister has authorised the Special Minister of State

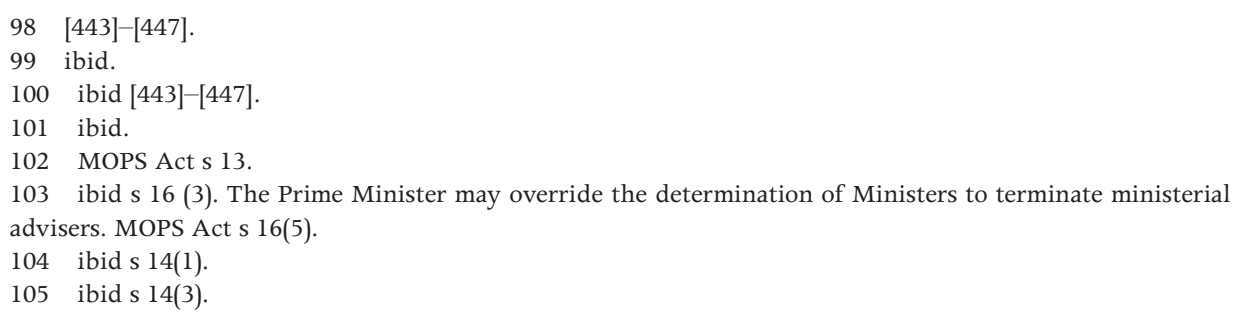


to exercise some powers under the Act. ${ }^{106}$ Further, the salaries of ministerial advisers are appropriated from public funds. Although the Prime Minister is able to override the decision of the Minister for their ministerial advisers, the Prime Minister is part of the Commonwealth and this employment structure still demonstrates complete control by the Commonwealth over ministerial advisers.

Ministerial advisers thus fulfil the criteria in case law as they are appointed and removable by Ministers and their salaries are appropriated from public money. They are appointed as individuals and not corporations. Ministers and the Prime Minister have full control of the terms and conditions of employment of ministerial advisers. Hence the relationship between Ministers and ministerial advisers demonstrates complete control of the Ministers over their advisers such that ministerial advisers would constitute 'officers of the Commonwealth'.

In addition, the main purpose of section $75(\mathrm{v})$ is to ensure judicial supervision over the exercise of executive and statutory power. ${ }^{107}$ This is done by ensuring that actions of officers of the Commonwealth are lawful. Griffith CJ has indicated that where the meaning of the words of section 75 is ambiguous, 'the ambiguity should be resolved in favour of the power' ${ }^{108}$ Barton $\mathrm{J}$ also suggested that the context gives section $75(\mathrm{v})$ 'a very extensive meaning' ${ }^{109}$ Barwick CJ said that the High Court should itself be 'jealous to preserve and maintain the scope of the power'. ${ }^{110}$

Therefore, there is a strong argument that ministerial advisers are 'officers of the Commonwealth'. As such, they are subject to judicial review through the original jurisdiction of the High Court when they exercise executive power. Thus, the remedies of injunction, prohibition and mandamus are available against ministerial advisers.

\section{Conclusion}

Ministerial advisers occupy an uncertain position in the operation of the executive arm of government as they are employed by Ministers personally and report directly to Ministers. It is unclear if their accountabilities extend beyond accountability to Ministers as part of a normal employment contract.

\footnotetext{
106 Enterprise Agreement 2012-2015, http://maps.finance.gov.au/enterprise_agreement/index.html.

107 Mark Aronson, Bruce Dyer and Matthew Groves, Judicial Review of Administrative Action (Thomson Reuters, 4th ed, 2009) 40.

$108 R v$ Commonwealth Court of Conciliation \& Arbitration; ex parte Whybrow \& Co (1910) 11 CLR 1, 22.

$109 R v$ Commonwealth Court of Conciliation \& Arbitration; Ex parte Brisbane Tramways Co Ltd (1914) 18 CLR 54, 66 .

$110 R v$ Judges of the Federal Court of Australia; ex parte the Western Australian National Football League (Incorporated) (1979) 143 CLR 190, 201.
} 
The traditional actors within the executive of the Queen, Governor-General, Ministers and public servants are no longer the only actors who engage in public functions. The scope of governmental activity has increased over the years. Some traditional functions of government have been outsourced to private entities. Governing has become more complex and demanding following the 24/7 news cycle such that Ministers are unable to cope with the workload themselves and employ ministerial advisers to assist them. Ministerial advisers clearly perform public functions affecting the governing of the nation. Nevertheless, they are external to the public service, with a separate employment framework. ${ }^{11}$

The idea of partisan advisers for Ministers was denigrated by the framers of the Constitution as being corrupt and undesirable. ${ }^{112}$ The ideal of the impartial public service continues to this day in spirit, as seen in the statement of Australian Public Service Values. ${ }^{113}$ However, the reality may not completely reflect this, given that the senior public servants of departments are now on fixed-term contracts and can be removed easily by the Ministers if they fall out of favour. ${ }^{114}$ This means that public servants are less likely to be 'frank and fearless' and impartial in their advice than if their positions were permanent. Further, ministerial advisers have slowly and steadily grown as an institutionalised source of advice - a phenomenon that would have been considered very undesirable at federation. There has been a distinct shift in attitude towards partisan ministerial advisers being a formalised part of government, with their position officially recognised through statute. ${ }^{115}$

The issue of accountability is challenging for ministerial advisers. Although their salary is appropriated from public funds and they are close to the political and policy workings of the government and Parliament, they do not officially sit in the Houses of Parliament. This means that they are not directly subject to political accountability through Parliament. Further, ministerial advisers are not located within departments and statutory authorities, suggesting they are outside the traditional administrative law framework.

Although ministerial advisers are personally employed by Ministers in their private offices, they perform many public functions, including advising on public policy, media, political, parliamentary management and party management matters. ${ }^{116}$ Increasingly, ministerial advisers also exercise executive power.

\footnotetext{
111 Public servants are appointed under the Public Service Act 1999 (Cth), while ministerial advisers are appointed under the Members of Parliament (Staff) Act 1984 (Cth).

112 Official Report of the National Australasian Convention Debates, Adelaide, 19 April 1897, 916-7.

113 Australian Public Service Values, http://www.apsc.gov.au/aps-employment-policy-and-advice/apsvalues-and-code-of-conduct/code-of-conduct/aps-values.

114 Barratt v Howard (2000) 96 FCR 428, 451-452; Patrick Weller, Australia's Mandarins: The Frank and the Fearless? (Allen \& Unwin, 2001) 33.

115 MOPS Act.

116 The Herald and Weekly Times Pty Limited $v$ The Office of the Premier (General) [2012] VCAT 967 [22].
} 
Given that ministerial advisers have become an integral part of the executive and may exercise executive power in some instances, I argue that ministerial advisers should be subject to appropriate public law accountability mechanisms. For instance, ministerial advisers should be accountable to Parliament through being made to appear before parliamentary committees. There can also be accountability through courts, utilising the mechanism of judicial review for the executive decisions of ministerial advisers. Other actors within the executive, such as Ministers and public servants, are subject to a plethora of accountability mechanisms, such as through Parliament, the courts and administrative law mechanisms, such as tribunals, ombudsmen, the Auditor-General and freedom of information legislation. However, current public law mechanisms have not yet been applied to ministerial advisers due to their relatively new status as independent and significant actors within the contemporary executive.

In conclusion, ministerial advisers are significant new institutional actors in the executive. Due to their increasing roles within the executive, I argue that ministerial advisers should be subject to public law accountability mechanisms. As ministerial advisers are now part of the operation of the executive, so too should their accountabilities increase. 
This text taken from Law and Democracy: Contemporary questions, edited by Glenn Patmore and Kim Rubenstein, published 2014 by ANU Press, The Australian National University, Canberra, Australia. 